\title{
A Study on the Immune Status of Children with Wheezing and Parasitic Infection
}

\author{
D. Joseph Pushpa Innocent ${ }^{1 *}$, T. Sheila Doris Devamani ${ }^{1}$, \\ Margaret Theresa $^{2}$ and Ajithkumar ${ }^{1}$
}
${ }^{1}$ Department of Microbiology, ${ }^{2}$ Department of Pathology, Karpaga Vinayaga Institute of Medical Sciences and Research Centre, Maduranthagam, Kanchipuram, India

*Corresponding author

\section{Ke y w ords \\ Wheezing children, IgE antibody, Allergy, Parasite infection, Entamoeba histolytica \\ Article Info \\ Accepted: \\ 26 July 2018 \\ Available Online: \\ 10 August 2018}

\section{A B S T R A C T}

The aim of this study was to identify the parasitic infection and the associated allergic condition by studying the stool samples of the wheezing children and to correlate, the total serum IgE antibody levels in those children. Further to study the type of parasites commonly involved in these rural area. A total of 76 stool and blood samples were collected from the wheezing children attended the allergy clinic at the Pediatric out patent department of Karpaga Vinayaga Institute of Medical Science and Research Centre, during a period of six months. Stool samples of children were examined microscopically for the presence of ova/ cysts/ whole parasite and the body segments using saline and iodine wet mount preparations. Serum samples were tested for total IgE antibodies by Turbidimetric immunoassay. Results were analyzed, among the 76 stool samples examined from the wheezing children, 48 are found to be positive contributing to a prevalence of $63.2 \%$ of intestinal parasitic infection in the study population. The most common intestinal parasite was found to be Entamoeba histolytica (33.3\%) followed by hook worm $(27.1 \%)$ and Giardia intestinalis (23\%). Other less commonly detected parasites were cyst of $E$. coli in 5 cases (10.4\%), ova of Ascaris lumbricoides (6.2\%). A high prevalence of intestinal parasites was observed in the wheezing children. Further the children with parasite infection showed a higher level of total IgE in their serum.

\section{Introduction}

Literature survey showed that the wheezing in children in a common respiratory symptoms in allergic condition (Fernando, 2002). Poor hygienic practice may cause parasite infection among children. In rural area the periodical de worming is not done regularly in childhood (Luong, 2004). Parasite infection is one of the triggering factors of wheezing in children
(Kunst et al., 2009). In allergic condition the IgE antibody level will be increased (Manohar et al., 2012). Immunity in secretary regions are maintained by IgA class of antibodies (Harry W. Schroeder et al., 2010). When the $\operatorname{Ig} \mathrm{A}$ level in those regions decreased by any chance, then the microbes may invade the areas such as respiratory and intestinal mucosa (Nicholas J. Mantis et al., 2013). In such conditions the foreign antigens 
may induce the allergic response of the host (Norman et al., 1998). Ultimately the $\operatorname{IgE}$ antibodies were induced and increased (Thomas, 2001). Therefore it is a fact that IgA and $\mathrm{IgE}$ titers are inversely proportional (Michael et al., 2010). In some cases there will be an infection, but there was no induction of antibody against the infection, infers the immunodeficiency of the individual (Andrea Lantz et al., 2001). Hence this study was planned to analyze the immune status of the children showed the signs and symptoms of allergy and to rule out the role of parasitic infection and the associated IgE level in such conditions.

Worldwide about 3.5billion of population is infected with intestinal parasites, which include mostly children (WHO, 1998). As reported by World Health Organization (WHO) more than 1.5 billion people are infected with contaminated soil (Blouin et al., 2018). These infections are distributed in tropical and subtropical areas, with the majority occurring in developing countries. The warm and moist climate of tropical and subtropical countries provides the ideal environment for the survival of parasite eggs or larvae of these four soil transmitted helminth (STH), roundworm (Ascaris lumbricoides), whipworm (Trichuris trichiura) and hookworm (Necator americanus, Ancylostoma duodenale) (Brooker et al., 2006). It is mentioned that approximately 270 million children in the preschool-age and nearly 600 million in school-age are living in areas associated with intensive transmission of intestinal parasites (WHO, 2014). There by necessitating treatment and prevention.

In India the prevalence rates greatly varies due to environmental, climatic and socioeconomic conditions. Various studies reported on the prevalence of parasitic infection are as follows $49 \%$ in East Godavari of Andhra
Pradesh (Padmaja et al., 2015), $75.28 \%$ in Kashmir (Wani et al., 2007), 51.5 \% in Karnataka (Shubha et al., 2011) and 26.88 \% in East Delhi (Mahajan et al., 1993). Among the protozoan parasites, Entamoeba histolytica, Giardia intestinalis and coccidian parasites are common in children. Whereas the most common helminthes detected in children is Ascaris lumbricoides and it is the common parasite found in India followed by Hookworm, Hymenolepis nana, Tapeworm, Trichuris trichiura, Enterobius vermicularis, Entamoeba histolytica, Entamoeba coli and Giardia lamblia (Virk et al., 1994).

Several socio-economic, personal and environmental factors like poverty, illiteracy, lack of safe water for drinking, overcrowding, poor personal hygiene, lack of toilet facilities and several other factors are associated with occurrence of intestinal parasitic infection in children (Padmaja et al., 2014; Mane et al., 2014).

\section{Materials and Methods}

Seventy six stool samples were collected from children from the age group of 3 to 13 years, showing signs and symptoms of wheezing who attended the children OPD for treatment at Karpaga Vinayaga Institute of Medical science and Research Centre, Cinnakolambkkam for a period of six months between March 2017 and August 2017.

The study was explained to the parents of the child before collect their personal, medical history and specimens. Further this study was approved by the Institute Ethical Committee. Stool samples were collected in a clean and wide mouth container without contaminating urine. Similarly $2 \mathrm{~mL}$ of blood samples were also collected aseptically in a sterile vial from those children and allowed for 20 minutes at room temperature for clot formation. After retraction of the clot the vials are centrifuged 
at $2500 \mathrm{RPM}$ for 20 minutes. The clear sera were collected in a vial and labeled. Stool and the serum samples were transported immediately to the Microbiology department. The cross sectional study was carried out in the department of Microbiology.

\section{Identification of parasites in stool}

\section{Macroscopic examination}

Macroscopic examination of stool includes the observation of odour, consistency, color and presence of blood, mucus or segments of adult worms. Liquid specimens are examined within 30 minutes for trophozoite detection and semisolid specimens within 60 minutes. Preservatives like formalin, polyvinyl alcohol (PVA) were used whenever preservation is needed.

\section{Microscopic examination}

Freshly passed stool specimens were collected in clean dry container and are examined immediately. Stool sample were examined microscopically for the presence of ova/ cysts/ whole parasite and the body segments in wet mount preparations with $0.9 \%$ saline and Dobell's iodine. Saline mount for the visualization of bile staining property of eggs, live motile larvae or trophoziotes and the iodine mount for the in better visualization of finer objects like nuclei. In certain conditions like enterobiasis, peri-anal swab using NIH swab or Scotch cellulose adhesive tape were used. The parasites were identified by their specific morphology of ova/cyst etc.

\section{Estimation of total IgE}

The serum samples of the children were tested for the presence of $\operatorname{IgE}$ antibodies by Turbidimetric immunoassay using QuantiaIgE kit. A Calibrator curve was constructed using with the given known concentration of calibrator and its different concentrations prepared by serial dilution with saline. Spectrophotometer was adjusted to read zero with saline at $630 \mathrm{~nm}$ wave length. As per the procedure of the kit the activation buffer and the Quantia $\operatorname{IgE}$ reagents were mixed and incubated in a curette for 5 mints at $37{ }^{\circ} \mathrm{C}$, and added the calibrator mixed well and incubated. Absorbance values were measured at the end of 10 seconds (A1) and again at the end of 4 minutes (A2). A2-A1 gives the absorbance value (A) of that concentration. The same procedure was repeated with the other serially diluted calibrators and their absorbance values were noted using the Instrument and the values were calculated. A graph was plotted on the absorbance versus the concentration of the calibrators. The same procedure was repeated for each of the serum samples collected from the children and the absorbance values were measured. Making use of the calibrator curve the Total IgE values were calculated for each of the serum sample collected.

\section{Results and Discussion}

\section{Characteristics of study population}

A total of 76 wheezing children were included in this study, of which 42 were boy children $(55.3 \%)$ and 34 were girls $(44.7 \%)$ among the 42 boys 27 were showed positive reports $(64.3 \%)$ whereas among the 34 girls 21 showed positive $(61.8 \%)$ for parasites. Majority of children were in the age group of 6-10 years $42(47.4 \%)$ followed by children of age group less than 5 years of age contributed $28(36.8 \%)$. The age group between $11 \geq 13$ years only 12 $(15.8 \%)$.Presence of parasites in various age groups were as follows among the group $3 \leq 5$ years $24(50 \%)$, in group 6-10 years 22 $(45.8 \%)$ and in group $11 \geq 13$ years of age only $2(4.2 \%)$ were positive for parasitic infection (Table 1). 
Prevalence of intestinal parasitic infections

Among the 76 stool samples examined from the wheezing children, 48 were found to be positive contributing to a prevalence of 63.2 $\%$ of intestinal parasitic infection in the study population. The most common intestinal parasite was found to be Entamoeba histolytica $(33.3 \%)$ followed by hook worm $(27.1 \%)$ and Giardia intestinalis (23\%).
Other less commonly detected parasites were cyst of E.coli in 5 cases (10.4\%), ova of Ascaris lumbricoides (6.2\%). Shown in table 2.

It was observed that the cyst of Entamoeba histolytica and the eggs of Hookworm are the most commonly present parasites in our study population.

Table.1 Distribution of intestinal parasite in stool samples

\begin{tabular}{|c|c|c|c|}
\hline \multirow[t]{2}{*}{ Factors } & \multirow[t]{2}{*}{$\mathbf{N}=76$} & \multicolumn{2}{|l|}{ Parasite } \\
\hline & & $\begin{array}{l}+\mathrm{ve}=48 \\
(63.2 \%)\end{array}$ & $\begin{array}{c}-- \text { ve }=28 \\
(36.8 \%)\end{array}$ \\
\hline $\begin{array}{l}\text { Age } \\
3 \leq 5 \\
6-10 \\
11 \geq 13\end{array}$ & $\begin{array}{l}28(36.8 \%) \\
36(47.4 \%) \\
12(15.8 \%)\end{array}$ & $\begin{array}{l}24(50.0 \%) \\
22(45.8 \%) \\
02(04.2 \%)\end{array}$ & $\begin{array}{l}04(14.3 \%) \\
14(50.0 \%) \\
10(35.7 \%)\end{array}$ \\
\hline $\begin{array}{l}\text { Sex } \\
\text { Boys } \\
\text { Girls }\end{array}$ & $\begin{array}{l}42(55.3 \%) \\
34(44.7 \%)\end{array}$ & $\begin{array}{l}27(64.3 \%) \\
21(61.8 \%)\end{array}$ & $\begin{array}{l}15(35.7 \%) \\
13(38.2 \%)\end{array}$ \\
\hline $\begin{array}{l}\text { Monthly income } \\
\leq \mathbf{5 0 0 0} \\
\mathbf{5 0 0 1 - 1 0 0 0 0} \\
\mathbf{1 0 0 0 1 - 2 0 0 0 0} \\
>\mathbf{2 0 0 0 0}\end{array}$ & $\begin{array}{l}13(17.1 \%) \\
43(56.6 \%) \\
11(14.5 \%) \\
09(11.8 \%)\end{array}$ & $\begin{array}{l}11(22.9 \%) \\
31(64.6 \%) \\
05(10.4 \%) \\
01(2.1 \%)\end{array}$ & $\begin{array}{l}02(07.1 \%) \\
12(42.9 \%) \\
06(21.4 \%) \\
08(28.6 \%)\end{array}$ \\
\hline
\end{tabular}

Table.2 Prevalence of Intestinal parasites

\begin{tabular}{|c|c|c|c|}
\hline Sl.no & Parasite & $\begin{array}{c}\text { Number of } \\
\text { Samples (48) }\end{array}$ & $(\%)$ \\
\hline $\mathbf{1}$ & Entamoeba histolytica & 16 & $33.3 \%$ \\
\hline $\mathbf{2}$ & Entamoeba coli & 05 & $10.4 \%$ \\
\hline $\mathbf{3}$ & Hookworm egg & 13 & $27.1 \%$ \\
\hline $\mathbf{4}$ & Ascaris lambricoides & 03 & $06.2 \%$ \\
\hline $\mathbf{5}$ & Giardia intestinalis & 11 & $23.0 \%$ \\
\hline
\end{tabular}


Table.3 Total serum IgE antibody levels in various groups of children

\begin{tabular}{|l|l|l|l|}
\hline $\begin{array}{l}\text { CATEGORY OF } \\
\text { CHILDREN }\end{array}$ & No studied & $\begin{array}{l}\text { IgE level } \\
(\text { mean } \pm \text { SE IU/mL) }\end{array}$ & P valve \\
\hline WITH WHEEZE & 76 & $1194.2 \pm 169.4$ & $\mathbf{P}<0.001$ \\
\hline $\begin{array}{l}\text { WITH PARASITE } \\
\text { INFECTED }\end{array}$ & 48 & $1527.0 \pm 176$ & $\mathbf{P}<0.001$ \\
\hline HEALTHY CONTROLS & 10 & $160.4 \pm 57.16$ & $\mathbf{P}<0.001$ \\
\hline
\end{tabular}

The total serum IgE antibody levels in children

Among the 76 children aged between 3 and 13 years with signs and symptoms of wheeze when tested for the total $\mathrm{IgE}$ level using Turbidimetric immunoassay a mean IgE level of $1194.2 \pm 169.4 \mathrm{IU} / \mathrm{mL}$ was observed. Whereas the total level of Ig E of the parasite infected 48 children showed a mean Ig E level of $1527 \pm 176 \mathrm{IU} / \mathrm{mL}$. When we tested a control group of 10 healthy children with non wheezing and parasitic infection showed a mean Ig E level of only $160.4 \pm 57.16 \mathrm{IU} / \mathrm{mL}$ $(\mathrm{p}<0.001)$ (Table 3).

Detection of the immune status of the wheezing children infected with parasites were studied by serum $\operatorname{IgE}$ and the levels of each of the children were analyzed and were compared and correlated with the reports of the stool sample studies.

Increasing prevalence of wheezing is one of the common chronic disorders of the children It has been associated with increased exposure to environmental allergens. Literature survey revealed that the bacteria and virus may also cause exacerbation of asthmatic wheezing. The present study was planned to understand the parasitic infection and its role in causing asthmatic wheezing in children. The results showed a lot of parasites infect the gastro intestinal tract in children. Reports suggested the invasive larvae during its migration through the lungs induce a strong eosinophil rich inflammation in the lungs. Intestinal helminthes infection may also capable of enhancing allergic inflammation (Van den Bigelaar et al., 2000). The study report explained the association of the parasites and its capability of enhancing allergic inflammation. Yet another study it was stated that $A$. lumbricoides was associated with increased risk of Asthma (Leonardi-Bee et al., 2006). In the present study stool samples were collected from the children who were suffered from asthmatic wheeze. Presence of ova of Ascaris lumbricoides and some other parasites in the samples of affected children correlate with other studies. Allergy is IgE mediated type I hypersensitivity (Mathias 2011). In normal condition the serum $\operatorname{IgE}$ is present in trace amounts. Usually the total IgE level increases with amount of exposure to relevant allergens (Gruchalla et al., 2005). Measurement of serum IgE is useful to determine if the allergic reaction is $\operatorname{IgE}$ mediated and its level increases in parasitic infection (Bell, et al., 1996). Various study report indicated a significant fall in IgE concentration after effective therapy. Present study reports conclude that a number of wheezing children showed ova and cysts in their stool samples indicating the parasitic infection. Wheezing children with parasite infection showed a higher level of total IgE in their serum. This base line data may be fine-tuned by further investigations with more number of cases and allergen specific IgE antibody tests. 


\section{Acknowledgement}

Authors acknowledge the Managing director KIMS for the financial support for this project and for the constant encouragement. The author is also grateful to authors/ editors/ publishers of all those articles, journals and books from where the literature for this manuscript has been reviewed and discussed.

\section{References}

Van den Bigelaar AHJ, Van Ree R, Rodrigues LC, Lell B, Deelder AM,Kremsner PG, Yazdanbakhsh M. (2000). Decreased atopy in children infected with Schistosoma hematobium: Arole of parasite inducedinterleukin-10. Lancet. 356:1723-7.

.Mane M, Kadu A, Mumbre S, Deshpande M, Gangurde N. 2014. Prevalence of intestinal parasitic infections and associated risk factors among preschool children in tribal villages of North Maharashtra, India. Int J Res Health Sci; 2(1):133-9

Andrea Lantz MD. Jack Armstrong MD Bettywray MD.2001.Immunoglobulin deficiency in children with a sudden overwhelming infection. Annals of allergy, asthma and immunology. vol. 86(1): 55-58.

Bell, RG., JA Baker., (1996).Institute for Animal Health, IgE, allergies and helminth parasites: A new perspective on an old conundrum Immunology and Cell Biology volume74, pages337-345

Blouin B, Casapía M, Joseph L, Kaufman JS, Larson C, Gyorkos TW. 2018. The effect of cumulative soil-transmitted helminth infections over time on child development: a 4-year longitudinal cohort study in preschool children using Bayesian methods to adjust for exposure misclassification. Int $\mathbf{J}$ Epidemiol. 2018 Jul 12. doi: 10.1093/ije/dyy142. [Epub ahead of print]

Brooker S, Clements AC, Bundy, DA., 2006. Global epidemiology, ecology and control of soil-transmitted helminth infections. Adv Parasitol.;62: 221-61

Gruchalla RS, Pongracic J, Plaut M, Evans R, 3rd, Visness CM, Walter M., 2005 Inner City Asthma Study: relationships among sensitivity, allergen exposure, and asthma morbidity. J Allergy Clin Immunol.; 115: 478-485. [PubMed]

Harry W Schroeder, Jr., Lisa Cavacini. 2010.

Structure and Function of Immunoglobulins. Volume 125, Issue 2, Supplement 2, S1-S394 Edited by William T. Shearer, Donald Y.M. Leung.

Kunst, H., D Mack, O M Kon, AK Banerjee, P Chiodini, A Grant. 2009. Parasite infections of the lung: A guide for the respiratory physician. Thorax 66(6):528-36 · September 2010 with 325 Reads DOI: 10.1136/thx.2009. 132217.

Leonardi-Bee J, Pritchard D, Britton., (2006). J. Asthma and current intestinal parasite infection: systematic review and metaanalysis. Am J Respir Crit Care Med 174:514-2310.1164/rccm.200603331OC[PubMed]

Luong, TV., 2004. De worming school children and hygiene intervention. Pages S153-159. Published online 06 Aug 2010.

Mahajan M, Mathur M, Talwar V, Revathi G. 1993. Prevalence of intestinal parasitic infections in East Delhi. Indian $\mathbf{J}$ Community Med; 111: 177-9

Manohar,S., R.Selvakumaran, 2012. European Journal of Experimental Biology 2 (6):2199-2205

Mathias, C. B. et al. (2011). IgE-mediated systemic anaphylaxis and impaired tolerance to food antigens in mice with enhanced I-4 receptor signaling. $J$ 
Allergy Clin. Immun. 127, 1-6

Matinez,D., 2002. Development of wheezing disorders and asthma in preschool children. vol- 109/ issue From the American Academy of Pediatrics.

Michael E. Possin, Stephanie Morgan, and James, E., 2010. The relationships among Ig levels, Allergic Sensitization. Gern Pediatr allergy immunol; Sep: 21 (6): 990-996

Nicholas J. Mantis., Nicolas Rol., Blaise Corthésy, (2011). Secretory IgA's complex roles in immunity and mucosal homeostasis in the gut. Mucosal Immunology volume4, pages 603-611.

Norman H. Edelman., Edelman, M.D. 1998. The American Lung Association Asthma advisory group, Family Guide to asthma and Allergies: How you and your children can breath Easier, Boston: Litte Brown. Padmaja, Swaroop S. Nageswararao P. 2014. Prevalence of Intestinal Parasitic Infections among School Children in and around Amalapuram. J Pub Health Med Res;2(2):36-8.

Platts-mills,E., A,Thomas., 2001.The role of
Ig $\mathrm{E}$ in allergy and asthma https://doi.org/10.1164 /ajrccm.164. supplement_1.2103024 PubMed: 11704610

Shubha, DS., Fatima, F., 2007. A coprological survey for assessing intensity of parasitic infection in school children: Crosssectional study. Trop Parasitol 2011;1:88-93.

Virk KJ, Prasad RN, Prasad H. 1994. Prevalence of intestinal parasites in rural areas of district Shahjahanpur, Uttar Pradesh. J Commun Dis; 26(2): 103-8[PubMed]

Wani SA, Ahmad F, Zargar SA, Ahmad Z, Ahmad P, Tak H.,2007. Prevalence of intestinal parasites and associated risk factors among schoolchildren in Srinagar City, Kashmir, India.J Parasitol; 93(6): 1541-3.

WHO (2014). Fact sheet no 366. Available online athttp;//www.who.int/worm control. Accessed June 25, 2014.

WHO(1998). Control of Tropical Diseases. Kashmir, India World Health Organization, Geneva [Ref list]

\section{How to cite this article:}

Joseph Pushpa Innocent, D., T. Sheila Doris Devamani, Margaret Theresa and Ajithkumar. 2018. A Study on the Immune Status of Children with Wheezing and Parasitic Infection. Int.J.Curr.Microbiol.App.Sci. 7(08): 4436-4442. doi: https://doi.org/10.20546/ijcmas.2018.708.468 